\title{
Analisis Kebutuhan Kualitas Data dan Aturan Bisnis Data Pendidikan
}

\author{
Anton Rahmansyah Sumadi, Nori Wilantika* \\ Program Studi Komputasi Statistik, Politeknik Statistika STIS \\ Jalan Otto Iskandardinata No. C64, Jakarta Timur, DKI Jakarta, Indonesia \\ *e-mail: wilantika@stis.ac.id
}

(received: 11 April 2021, revised: 11 September 2021, accepted: 22 September 2021)

\begin{abstract}
Abstrak
Politeknik Statistika STIS sebagai organisasi pendidikan tinggi harus memenuhi kebutuhan data penyelengaraan pendidikan yang diperlukan Pangkalan Data Pendidikan Tinggi (PDDikti) secara berkala. Penelitian sebelumnya menemukan bahwa Politeknik Statistika STIS memiliki masalah untuk memenuhi dimensi kualitas data yang dibutuhkan oleh PDDikti. Salah satu akar masalah yang menyebabkan kualitas data yang rendah pada organisasi Politeknik Statistika STIS adalah kurangnya kegiatan manajemen kualitas data dalam organisasi sehingga kualitas data tidak termonitor dengan baik. Penelitian ini bertujuan untuk melakukan kegiatan manajemen kualitas data yaitu mendefinisikan kebutuhan kualitas data dan mendefinisikan aturan kualitas data organisasi dalam bidang pendidikan, penelitian, dan pengabdian masyarakat. Metode pengumpulan data dalam penelitian ini terdiri dari studi dokumen, observasi, dan wawancara. Tahapan-tahapan analisis penelitian ini berhasil mengidentifikasi 15 proses bisnis, 12 aktor proses bisnis, dan 31 entitas data. Kebutuhan kualitas data Politeknik Statistika STIS berdasarkan penelitian ini adalah kelengkapan, akurasi, kebenaran, konsistensi, ketepatan waktu, kewajaran, keterkinian, dan keterlacakan. Dimensi kebutuhan kualitas data yang paling banyak ditemukan adalah kelengkapan dan akurasi. Penelitian ini berhasil mengidentifikasi 243 aturan kualitas data dan berhasil menyusun matriks penilaian kualitas data sebagai salah satu acuan yang diajukan untuk mengevaluasi kualitas data organisasi Politeknik Statistika STIS yang berhubungan dengan penyelenggaraan pendidikan akademik, penelitian, dan pengabdian masyarakat.
\end{abstract}

Kata kunci: kualitas data, kebutuhan kualitas data, aturan kualitas data

\begin{abstract}
Polytechnic of Statistics STIS as a higher education organization should periodically fulfill the requirement of education data provided by Pangkalan Data Pendidikan Tinggi (PDDikti). Previous research found that Polytechnic of Statistics STIS has problem to fulfill the data quality dimension required by PDDikti. One of the root cause of insufficient data quality on Polytechnic of Statistics STIS's organization is the lack of data quality management activity on the organization, thus resulting in lack of data quality monitoring. This research's objective is to conduct data quality management activities consisting of to define data quality requirement and to define data quality rules in scope of education, research, and community service. Data collection methods used in this research were document studies, observations, and interviews. Research's data analysis managed to identify 15 business processes, 12 process business actors, and 31 data entities. The data quality requirements of Polytechnic of Statistics STIS according of this research are completeness, accuracy, validity, consistency, timeliness, reasonableness, currency, and lineage. The most discovered dimensions of data quality requirement are completeness and accuracy. This research managed to identify 243 data quality rules and managed to formulate data quality assessment metrics as a proposed reference to evaluate data quality on Polytechnic of Statistics STIS's organization relating to academic education, research, and community service.
\end{abstract}

Keywords: data quality, data quality requirement, data quality rules 


\section{Pendahuluan}

Politeknik Statistika STIS adalah perguruan tinggi kedinasan yang berada di lingkungan Badan Pusat Statistik (BPS). Berdasarkan Pasal 2 Peraturan Kepala Badan Pusat Statistik Nomor 87 Tahun 2017 tentang Organisasi dan Tata Kerja Politeknik Statistika STIS, Politeknik Statistika STIS mempunyai tugas untuk menyelenggarakan jenis pendidikan vokasi, penelitian, dan pengabdian kepada masyarakat di bidang statistika dan komputasi statistik. Pembinaan Politeknik Statistika STIS secara teknis akademik dilaksanakan oleh Menteri Riset, Teknologi, dan Pendidikan Tinggi. Sedangkan untuk pembinaan secara fungsional dilaksanakan oleh Kepala Badan Pusat Statistik [1].

Untuk mencapai pendidikan tinggi yang bermutu, pemerintah menyelenggarakan sistem penjaminan mutu pendidikan tinggi untuk mendapatkan pendidikan bermutu [2]. Diamanatkan oleh Pasal 52 Ayat 3 dan 4 Undang-Undang Tahun 2012 Tentang Pendidikan Tinggi, sistem penjaminan mutu pendidikan tinggi ditetapkan oleh Menteri Riset, Teknologi, dan Pendidikan Tinggi serta didasarkan pada Pangkalan Data Pendidikan Tinggi. Untuk menjamin ketersediaan data pendidikan tinggi, dilaksanakan pendataan penyelenggaraan pendidikan tinggi melalui PDDikti [3]. Sebagai organisasi perguruan tinggi, Politeknik Statistika STIS harus menyampaikan secara berkala laporan tentang penyelenggaraan pendidikan tinggi ke PDDikti. Apabila gagal menyampaikan laporan penyelenggaraan pendidikan tinggi ke PDDikti secara berkala, Politeknik Statistika STIS dapat dikenai sanksi sesuai dengan ketentuan peraturan perundang-undangan [3] dan lulusannya bisa tidak diakui oleh Kemenristekdikti.

Politeknik Statistika STIS harus menyampaikan data penyelengaraan pendidikan ke PDDikti secara valid. Sesuai dengan Pasal 12 Ayat 2 Peraturan Menteri Riset, Teknologi, dan Pendidikan Tinggi Nomor 61 Tahun 2016, data yang dilaporkan ke PDDikti harus memiliki empat dimensi kualitas data yang harus dipertanggungjawabkan dalam pelaporannya. Keempat dimensi tersebut adalah kelengkapan (completeness), kebenaran (validity), akurasi (accuracy), dan kemutakhiran (currency). Politeknik Statistika STIS memiliki masalah untuk memenuhi dimensi kualitas data yang dibutuhkan oleh PDDikti. Berdasarkan penelitian yang dilakukan oleh [4], ditemukan bahwa kualitas data Politeknik Statistika STIS belum memenuhi keempat dimensi kualitas data yang dibutuhkan oleh PDDikti. Data Politeknik Statistika STIS baru memenuhi 11 dari 52 business rule $(21,25 \%)$ untuk dimensi completeness. Lalu, untuk dimensi validity baru memenuhi 11 dari 19 business rule (57.89\%). Selanjutnya, dimensi accuracy baru memenuhi 5 dari 11 business rule (45,45\%). Terakhir, dimensi currency tidak dapat diukur karena sistem database tidak memiliki kolom untuk menyimpan riwayat perubahan data. Penelitian tersebut menyimpulkan bahwa salah satu akar masalah yang menyebabkan kualitas data yang rendah adalah kurangnya kegiatan manajemen kualitas data dalam organisasi sehingga kualitas data tidak termonitor dengan baik.

Untuk memperbaiki kualitas data Politeknik Statistika STIS, [5] merekomendasikan delapan aktivitas manajemen kualitas data yang mengacu pada framework DAMA-DMBOK. [6]. Dua kegiatan yang direkomendasikan diantaranya adalah sebagai berikut:

1. Mendefinisikan kebutuhan kualitas data (data quality requirement). Kebutuhan kualitas data didefinisikan menurut konteks dari "ketepatan penggunaan" untuk mendukung proses bisnis organisasi. Dalam konteks Politeknik Statistika STIS, data diharapkan dapat membantu pembentukan keputusan dan mengandung indikator yang mendukung jaminan mutu internal. Kebutuhan kualitas data harus sejalan dengan kebutuhan BPS dan Kemenristekdikti.

2. Penelitian ini bertujuan untuk mengidentifikasi kebutuhan kualitas data untuk Mendefinisikan aturan bisnis kualitas data (data quality business rule). Kegiatan ini adalah lanjutan dari menentukan kebutuhan kualitas data. Kebutuhan kualitas data yang telah ditentukan akan lebih spesifik dijelaskan mengenai aturan-aturan pemformatan, nilai-nilai domain, dan deskripsi untuk setiap atribut. Aturan mengenai format-format data, nilai-nilai domain, dan deskripsi atribut dibutuhkan dalam proses standardisasi data untuk mempersingkat penanganan, penyimpanan, pengambilan, dan pembaruan data [7].

Organisasi Politeknik Statistika STIS. Selanjutnya, berdasarkan dari kebutuhan kualitas data yang dihasilkan, akan diidentifikasi aturan kualitas data yang lebih spesifik menjelaskan mengenai aturan format, nilai domain, dan deskripsi untuk setiap atribut data. Setelah kebutuhan kualitas data 
dan aturan kualitas data teridentifikasi, dirancanglah matriks penilaian kualitas data sebagai salah satu instrumen untuk mengevaluasi kualitas data Politeknik Statistika STIS secara berkala.

\section{Tinjauan Literatur}

\section{Kualitas Data}

Istilah data memiliki arti yang majemuk tergantung dalam konteks apa istilah tersebut dipakai dan dari referensi mana istilah tersebut dijelaskan. Untuk penelitian ini, konteks utama yang digunakan adalah data dalam konteks Politeknik Statistika STIS sebagai lembaga penyelenggaraan pendidikan tinggi. Data Pendidikan Tinggi adalah kumpulan fakta mengenai penyelenggaraan pendidikan tinggi yang dimanfaatkan untuk pembangunan pendidikan tinggi [3]. Dari definisi tersebut, dapat disimpulkan bahwa dalam konteks Politeknik Statistika STIS data adalah kumpulan fakta mengenai kegiatan pendidikan tinggi di Politeknik Statistik STIS yang dapat dimanfaatkan untuk mengembangkan kegiatan pendidikan tinggi di Politeknik Statistika STIS itu sendiri. Arti kualitas data secara harafiah adalah ukuran seberapa baik data dapat merepresentasikan fakta yang ingin direpresentasikan. Untuk menjaga kualitas data dalam organisasi, dibutuhkan manajemen kualitas data yang baik oleh organisasi tersebut. Program manajemen kualitas data dapat dilaksanakan berdasarkan kerangka kerja (framework) tertentu. Salah satu framework yang dipakai dalam memulai manajemen kualitas data adalah DAMA-Data Management Body of Knowledge [6]. DAMA-DMBOK diperuntukan sebagai pengenalan definitif ke manajemen data [6]. Fungsi manajemen kualitas data dalam framework DAMA-DMBOK adalah merencanakan, menerapkan, dan mengendalikan aktivitas yang menerapkan teknik manajemen kualitas untuk mengukur, menilai, meningkatkan, dan memastikan penggunaan data yang sesuai [6]. Terdapat dua belas aktivitas yang bisa dilakukan untuk manajemen kualitas data (data quality management). Aktivitas-aktivitas tersebut adalah [6]:

1. Mengembangkan dan mencanangkan sadar kualitas data

2. Mendefinisikan kebutuhan kualitas data (data quality requirement)

3. Memprofilkan, menganalisa, dan menilai kualitas data

4. Mendefinisikan ukuran kualitas data (data quality metrics)

5. Mendefinisikan aturan bisnis kualitas data (data quality business rule)

6. Menguji dan memvalidasi kebutuhan kualitas data

7. Mengatur dan mengevaluasi tingkatan layanan kualitas data (data quality service levels)

8. Mengukur dan memonitor kualitas data secara berkelanjutan

9. Memanajemen masalah kualitas data

10. Membersihkan dan memulihkan kecacatan kualitas data (data quality defects)

11. Mendesain dan mengimplementasikan prrosedur operasional manajemen kualitas data

12. Memonitor prosedur dan performa operasional manajemen kualitas data

Dari daftar aktivitas di atas, ada dua aktivitas manajemen kualitas data yang dijadikan fokus utama dalam penelitian ini, yaitu:

1. Mendefinisikan kebutuhan kualitas data (data quality requirement)

2. Mendefinisikan aturan bisnis kualitas data (data quality business rule)

\section{Kebutuhan Kualitas Data (Data Quality Requirement)}

Suatu kriteria dan ukuran harus menjelaskan tentang apa saja yang harus dibutuhkan untuk mencapai kualitas data yang baik. Kualitas data dapat diukur dengan bagaimana data tersebut dapat memenuhi ekspektasi pengguna data. Berdasarkan pendapat [8], tingkat kualitas data merepresentasikan seberapa besar data dapat memenuhi ekspektasi dari penggunanya berdasarkan bagaimana data tersebut seharusnya digunakan. Pendapat serupa juga diberikan oleh [6], kualitas data harus dapat dimengerti dalam konteks penggunaan yang sesuai. Dengan demikian, kebutuhan kualitas data adalah ukuran dan kriteria kualitas yang harus dipenuhi data agar penggunaan dan representasinya dapat memenuhi ekspektasi penggunanya.

Kualitas data mempunyai konsep kontekstual dan multidimensi, yang berarti hal tersebut dapat diukur dari berbagai dimensi yang berbeda [9]. Dalam pelaksanaan kualitas data, konsep 
dimensi yang terkandung dalam kualitas data mengklasifikasikan aspek dari kualitas data yang diharapkan dan memberikan ukuran untuk mengevaluasi kesesuaian dengan ukuran kualitas data tersebut [10]. Ukuran dari setiap dimensi kualitas data digunakan untuk mengukur dan untuk melihat dalam sisi mana data bisa ditingkatkan kualitasnya. Dalam [10] dan [6], dijelaskan beberapa dimensi praktis yang dapat digunakan untuk mengukur kebutuhan kualitas data.

\section{Aturan Bisnis Kualitas Data (Data Quality Business Rule)}

Dalam menentukan bagaimana data organisasi disimpan, dipertukarkan, atau direpresentasikan, data tersebut harus sesuai dengan aturan bisnis yang ada dalam organisasi tersebut. Oleh karena itu, dibutuhkan kriteria yang jelas mengenai apa dan bagaimana kualitas data yang sesuai dengan aturan bisnis di organisasi tersebut. [6] mengutarakan bahwa proses untuk membentuk ukuran kesesuaian kualitas data dengan aturan bisnis membutuhkan suatu definisi. Definisi tersebut didapatkan dengan mengumpulkan pernyataan aturan bisnis (business statement of the rule) dan menyampaikan pernyataan tersebut ke dalam spesifikasi aturan kualitas data (data quality rule specification). Business statement of the rule adalah pernyataan yang menjelaskan apa yang disebut kualitas data dalam istilah bisnis [11]. Sedangkan spesifikasi aturan kualitas data menjelaskan apa kualitas yang dipertimbangkan baik pada level fisik [11]. Jadi, aturan kualitas data berfungsi menjadi alat penerjemah antara kualitas data apa yang dikehendaki oleh organisasi dan bagaimana kualitas data akan diimplementasikan dalam bentuk nyatanya.

\section{Penelitian Terdahulu}

Beberapa penelitian terdahulu dapat menjadi rujukan untuk beberapa tahapan dalam penelitian ini. Penelitian-penelitian tersebut menjelaskan tentang bagaimana cara untuk mengidentifikasi proses bisnis, mengidentifikasi entitas data, serta merancang kebutuhan kualitas data. Penelitian "Data Quality Requirements of Collaborative Business Processes" oleh [12] bertujuan untuk mencari apa saja kebutuhan kualitas data dalam proses bisnis kolaboratif sebuah perusahaan. Penelitian tersebut membahas tentang proses bisnis kolaboratif yang di dalamnya ada pertukaran data antar perusahaan dan di mana saja data dan informasi tersebut dibuat dan diubah. Untuk mencari kebutuhan kualitas data dalam proses bisnis kolaboratif, dilakukan studi kasus Business Networking terhadap 12 perusahaan menggunakan analisis konten kualitatif (Qualitative Content Analysis) untuk dapat menjelaskan studi kasus jaringan bisnis untuk memecah kategori sistem berdasarkan kombinasi kelas data dan dimensi kualitas data [13]. Penelitian [12] menjelaskan salah satu metode untuk perancangan kebutuhan kualitas data dengan pengkodean kelas data dari dokumen-dokumen.

Penelitian "Arsitektur Data dan Informasi untuk Mendukung Perancangan Data Warehouse Perumahan" oleh [14] bertujuan untuk merencanakan arsitektur informasi dan pemodelan proses bisnis PT. Doboku Ligar Tasikmalaya agar mendukung perancangan data warehouse dalam perusahaannya. Sementara, Penelitian "Enterprise Architecture Planning Sistem Informasi Perusahaan Manufaktur (Studi Kasus : CV. Harta Jaya Perusahaan)" oleh [15] bertujuan untuk membuat model arsitektur enterprise perusahaan CV. Harta Jaya Pengemasan Air Minum Majair di Kabupaten Majalengka. Kedua penelitian tersebut menjelaskan langkah mendefinisikan proses-proses bisnis dan mendefinisikan entitas bisnis dan entitas data.

Penelitian "Pembuatan Arsitektur Data Di Perusahaan X" oleh [16] bertujuan untuk membuat model arsitektur data untuk suatu perusahaan yang bergerak dalam bidang otomotif dealer. Penelitian ini menjelaskan beberapa tahapan identifikasi proses bisnis dengan membuat narasi proses bisnis berdasarkan pengamatan terhadap kegiatan bisnis rutin di perusahaan tersebut.

\section{Metode Penelitian}

Metode yang digunakan pada penelitian ini adalah metode kualitatif dengan studi kasus Politeknik Statistika STIS. Metode pengumpulan data yang diterapkan terdiri dari studi pustaka, pengamatan, dan wawancara. Studi pustaka dilakukan dengan mencari informasi yang tersedia di berbagai dokumen yang menjelaskan proses-proses bisnis di Politeknik Statistika STIS. Dokumen 
yang dimaksud utamanya terdiri dari berbagai dokumen peraturan-peraturan yang ditetapkan oleh Kepala Badan Pusat Statistik dan Direktur Politeknik Statistika STIS. Selain itu, dokumen yang dipelajari juga berasal dari dokumentasi kegiatan, dokumen Standar Operasional Prosedur (SOP), serta dokumen pendukung yang menjelaskan kegiatan-kegiatan apa saja yang dilakukan Politeknik Statisika STIS terkait kegiatan pendidikan, kegiatan penelitian, dan kegiatan pengabdian dalam masyarakat. Adapun pengamatan dilakukan pada kegiatan rutin di Politeknik Statistika STIS seperti kegiatan belajar mengajar. Pengamatan dilakukan utamanya dalam sudut pandang sebagai mahasiswa. untuk memperhatikan alur dari proses kegiatan penyelenggaraan pendidikan, penyelenggaraan penelitian, serta pengabdian masyarakat.Selain itu, wawancara dilakukan untuk mencari kebutuhan kualitas data, isu-isu kebutuhan kualitas data, dan informasi proses bisnis di Politeknik Statistika STIS yang belum ditemukan pada metode studi pustaka dan pengamatan. Narasumber wawancara merupakan subject matter yang memiliki pengetahuan tinggi terhadap proses bisnis terkait di Politeknik Statistika STIS.

Metode utama yang digunakan untuk analisis data yang dikumpulkan adalah analisis konten kualitatif dengan metode kodifikasi. Analisis data dibagi menjadi beberapa tahapan. Yang pertama yaitu penggalian informasi terkait proses bisnis Politeknik Statistika STIS, yang bertujuan untuk memahami dan memetakan seluruh kegiatan yang ada di Politeknik Statistika STIS. Tahapan penggalian informasi proses bisnis menghasilkan output yang akan digunakan pada tahapan penelitian selanjutnya, yaitu identifikasi entitas data. Tahapan berikutnya adalah mengidentifikasi kebutuhan kualitas data dan aturan bisnis kualitas data. Tahapan yang terakhir yaitu penyusunan matriks penilaian kualitas data, yang dilakukan dengan memetakan hasil tahapan-tahapan analisis sebelumnya Matriks penilaian kualitas data adalah hasil akhir dari penelitian ini yang diharapkan dapat digunakan untuk menjadi salah satu acuan untuk mengevaluasi kualitas data Politeknik Statistika STIS. Berikut adalah rincian masing-masing tahapan penelitian yang telah disebutkan sebelumnya.

1. Identifikasi Proses Bisnis

Identifikasi proses bisnis di Organisasi Politeknik Statistika STIS dilakukan dengan menganalisis dokumen-dokumen yang mengandung informasi proses bisnis seperti data kualitatif dan pengamatan dari peneliti sebagai mahasiswa. Untuk memudahkan identifikasi proses bisnis, informasi yang tersebar dari berbagai dokumen terkait proses bisnis dikumpulkan menjadi satu dokumen berupa narasi proses bisnis. Teknik pengumpulan informasi proses bisnis menjadi sebuah narasi proses bisnis telah dilakukan dalam penelitian [16] untuk mempermudah identifikasi proses bisnis di perusahaan yang ditelitinya. Narasi proses bisnis dalam penelitian ini merupakan rangkuman tentang informasi proses bisnis Politeknik Statistika STIS yang terkait tentang penyelenggaraan pendidikan akademik, penelitian, dan pengabdian masyarakat. Dari narasi proses bisnis yang dihasilkan, selanjutnya dibuat pemodelan proses bisnis dan identifikasi entitas data. dalam bentuk activity diagram untuk memudahkan proses identifikasi kebutuhan kualitas data dan aktor-aktor yang berperan dalam proses bisnis tersebut.

Pencarian aktor proses bisnis dilakukan dengan analisis data kualitatif berupa kodifikasi dokumen narasi proses bisnis. Dalam penelitian ini, kodifikasi untuk identifikasi aktor dilakukan dengan dua siklus. Siklus pertama adalah dengan metode Simultaneous Coding [17]. Metode Simultaneous Coding dipilih karena kalimat-kalimat dalam narasi proses bisnis dapat mengandung informasi keterlibatan lebih dari satu aktor. Tahap kedua adalah dengan metode Pattern Coding [17]. Metode Pattern Coding digunakan dalam kodifikasi identifikasi aktor untuk mengelompokan aktoraktor yang sebelumnya diidentifikasi oleh metode Simultaneous Coding berdasarkan kemiripan aktoraktor tersebut. Hal ini dilakukan agar dapat mengurangi redundansi dari hasil identifikasi aktor-aktor. Hasil dari kodifikasi adalah daftar aktor-aktor yang teridentifikasi terkait dengan proses bisnis organisasi Politeknik Statistika STIS yang telah diidentifikasi sebelumnya. Proses Simultaneous Coding identifikasi aktor proses bisnis ditunjukan pada Tabel .

Setelah aktor-aktor yang terkait dengan proses bisnis diidentifikasi, maka dapat dilakukan pemodelan proses bisnis berupa pemetaan antara proses bisnis dengan aktor-aktor proses bisnis terkait. Aktor-aktor tersebut kemudian dipetakan ke dalam activity diagram proses bisnis untuk menggambarkan hubungan aktor dan proses-proses bisnis yang telah teridentifikasi sebelumnya. 
Tabel 1. Contoh Proses Simultaneous Coding Identifikasi Aktor dan Entitas Data

\begin{tabular}{|c|c|c|c|}
\hline Tema & Datum Narasi Proses Bisnis & $\begin{array}{l}\text { Kode Aktor } \\
\text { Teridentifikasi }\end{array}$ & $\begin{array}{c}\text { Kode Entitas } \\
\text { Data } \\
\text { Teridentifikasi }\end{array}$ \\
\hline $\begin{array}{c}\text { Pembentukan } \\
\text { Rombongan } \\
\text { Belajar }\end{array}$ & $\begin{array}{l}\text { Petugas BAAK membagi tiap } \\
\text { kelompok menjadi rombongan } \\
\text { belajar secara sistematik } \\
\text { sehingga distribusi rombongan } \\
\text { belajar menurut jenis kelamin, } \\
\text { program studi, daerah asal, dan } \\
\text { IP menjadi berimbang. }\end{array}$ & $\begin{array}{l}\text { PETUGAS } \\
\text { BAAK }\end{array}$ & $\begin{array}{c}\text { JENIS } \\
\text { KELAMIN, } \\
\text { PROGRAM } \\
\text { STUDI, } \\
\text { DAERAH ASAL, } \\
\text { IP } \\
\text { MAHASISWA, } \\
\text { ROMBONGAN } \\
\text { BELAJAR }\end{array}$ \\
\hline $\begin{array}{c}\text { Penilaian } \\
\text { Akademis } \\
\text { Mahasiswa }\end{array}$ & $\begin{array}{l}\text { Khusus mahasiswa Tingkat I, } \\
\text { Indeks Prestasi harus memenuhi } \\
\text { semua kriteria berikut: } \\
\text { Mahasiswa memperoleh minimal } \\
\text { huruf mutu C untuk mata kuliah } \\
\text { inti yang telah ditentukan, IPS } \\
\text { >= 2,00 untuk semester I dan II, } \\
\text { Apabila syarat tersebut tidak } \\
\text { terpenuhi, maka mahasiswa } \\
\text { tersebut dinyatakan drop out } \\
\text { (DO). }\end{array}$ & MAHASISWA & $\begin{array}{c}\text { MATA KULIAH, } \\
\text { NILAI MATA } \\
\text { KULIAH, } \\
\text { SEMESTER, } \\
\text { MAHASISWA, } \\
\text { IP SEMESTER, } \\
\text { STATUS } \\
\text { MAHASISWA }\end{array}$ \\
\hline
\end{tabular}

2. Identifikasi Entitas Data

Entitas data diperlukan untuk dapat menyusun kebutuhan kualitas data dan aturan bisnis kualitas data. Oleh karena perlu diidentifikasi entitas data yang terkandung dalam proses bisnis dalam organisasi tersebut. Penelitian [15] dan [14] menyertakan analisis daftar kandidat entitas data setelah identifikasi proses bisnis. Pada penelitian ini, identifikasi entitas data dilakukan dengan kodifikasi terhadap dokumen narasi proses bisnis. Kodifikasi entitas data dilakukan beriringan dengan kodifikasi aktor untuk melihat hubungan antara entitas data dan aktor yang terkait.

Serupa dengan kodifikasi aktor, teknik kodifikasi entitas data dilakukan dengan dua tahap. Tahap pertama adalah dengan metode Simultaneous Coding. Metode Simultaneous Coding [17] dipilih karena kalimat-kalimat dalam kodifikasi proses bisnis dapat mengandung informasi keterlibatan lebih dari satu entitas data dalam proses bisnis. Tahap kedua adalah dengan Pattern Coding. Metode Pattern Coding [17] digunakan untuk mengelompokan entitas-entitas data yang sebelumnya diidentifikasi oleh metode Simultaneous Coding berdasarkan kemiripan entitas data atau kecenderungan entitas data yang lebih sesuai menjadi atribut data untuk entitas data. Sehingga, mencegah terjadinya identifikasi entitas data yang terlalu banyak dan terlalu detil untuk dianalisis. Hasil dari identifikasi entitas data digunakan untuk identifikasi kebutuhan kualitas data dan identifikasi aturan kualitas data. Proses Simultaneous Coding identifikasi entitas data ditunjukan pada Tabel .

3. Identifikasi Kebutuhan Kualitas Data

Identifikasi kebutuhan kualitas data dilakukan untuk mengetahui apa saja dimensi-dimensi kebutuhan kualitas data berdasarkan informasi proses bisnis. Dalam penelitian [12], teknik kodifikasi terhadap dimensi kualitas data dan kelas data dilakukan dengan Axial Coding dan Selective Coding. [12] menggunakan metode kodifikasi ini untuk mencari tahu kelas data yang muncul dari teks referensi proses bisnis, juga mencari dimensi kualitas data dari teori yang sudah didapatkan sebelumnya maupun dimensi baru yang belum dijelaskan di teori sebelumnya. Dalam penelitian ini, 
walaupun prinsip untuk mendapatkan kebutuhan kualitas data mengikuti referensi [12], namun metode kodifikasi yang digunakan berbeda dari penelitian tersebut. Guna mengidentifikasi kebutuhan kualitas data, penelitian ini mengunakan metode Hypothesis Coding [17]. [17] menjelaskan bahwa Hypothesis Coding adalah metode kodifikasi dengan menggunakan kode yang telah dibuat, ditentukan, atau dikembangkan peneliti berdasarkan teori maupun prediksi sebelumnya. Metode kodifikasi ini dipilih karena berbeda dengan tahap analisis [12] yang memungkinkan identifikasi dimensi kualitas data dan kelas data yang baru, tahapan analisis ini bertujuan untuk mendeduksi kebutuhan kualitas data dari aktor proses bisnis berdasarkan referensi yang sudah ada sebelumnya. Proses Hypothesis Coding dicontohkan pada Tabel .

Tabel 2. Contoh Proses Hypothesis Coding Identifikasi Kebutuhan Kualitas Data

Sumber Datum Keterangan Aktor Proses Bisnis $\quad$ Dimensi Kualitas

Data Teridentifikasi

(Entitas Data

Terkait)

\begin{tabular}{clc}
\hline Wawancara & Kalau pendaftaran zaman sekarang yang & KELENGKAPAN \\
Aktor BAAK & melalui SSCASN, data yang diisikan & (mahasiswa) \\
& banyak sekali sampai NIK orang tua, & \\
& pekerjaan ayah dan ibu, gaji ayah dan gaji & \\
& ibu, semua itu memang dibutuhkan dan \\
& datanya memang dibutuhkan oleh PDDikti. & \\
& Jadi data mahasiswa yang seharusnya kita & \\
& miliki sekarang itu memang harus lengkap & \\
& banget. & \\
Kalau terkait kelulusan atau kenaikan & KELENGKAPAN \\
Wktor Program & tingkat, itu hanya berdasarkan dua. Nilai & (nilai akademik, nilai \\
Studi & akademik atau nonakademik. Kalau & nonakademik) \\
& nonakademik kan pelanggaran, datanya ada & AKURASI \\
& di BAAK, tercatat semua. Kalau kurang & (nilai akademik, nilai \\
& dari 55 maka tidak bisa naik, atau terkena & nonakademik) \\
& pelanggaran disiplin berat. Itu sudah jelas & \\
& semuanya, jadi sudah diatur di situ. & \\
\hline
\end{tabular}

Teori untuk menentukan kode dimensi kebutuhan kualitas data mengikuti referensi yang diberikan [10] dan [6]. Sementara, dalam menentukan kode entitas data, referensi yang digunakan adalah hasil identifikasi entitas data yang dilakukan pada tahapan analisis sebelumnya. Daftar dimensi-dimensi kualitas data yang menjadi dasar kodifikasi kebutuhan kualitas data tertera pada Tabel 3.

Tabel 3. Daftar Dimensi Kualitas Data Berdasarkan Teori

\begin{tabular}{ll}
\hline Dimensi Kualitas Data berdasarkan [6] & \multicolumn{1}{c}{ Dimensi Kualitas Data berdasarkan [10] } \\
\hline Akurasi (Accuracy) & Akurasi (Accuracy) \\
\hline Kelengkapan (Completeness) & Keterlacakan (Lineage) \\
\hline Konsistensi (Consistency) & Konsistensi Struktural (Structural Consistency) \\
\hline Kemutakhiran (Currency) & Konsistensi Semantik (Semantic Consistency) \\
\hline Presisi (Precision) & Kelengkapan (Completeness) \\
\hline Privasi (Privacy) & Konsistensi (Consistency) \\
\hline Kewajaran (Reasonableness) & Kemutakhiran (Currency) \\
\hline Integritas Referensi (Referential & Ketepatan Waktu (Timeliness) \\
Integrity) & \\
\hline Ketepatan Waktu (Timeliness) & Kewajaran (Reasonableness) \\
\hline Keunikan (Uniqueness) & Keindetifikasian (Identifiability) \\
\hline Kebenaran (Validity) & \\
\hline \multicolumn{1}{c}{ Sumber: [6] dan [10] }
\end{tabular}


Kodifikasi kebutuhan kualitas data dilakukan terhadap dokumen transkrip hasil wawancara dengan narasumber aktor-aktor proses bisnis terkait. Hasil dari identifikasi kebutuhan kualitas data adalah pemetaan dimensi-dimensi kualitas data terhadap entitas data serta daftar isu dalam pemenuhan kualitas data yang menjadi bahan kesimpulan dari penelitian ini.

\section{Identifikasi Aturan Kualitas Data}

Identifikasi aturan kualitas data dilakukan dengan mengkonversi pernyataan bisnis (businesss statement) yang muncul dari keterangan aktor proses bisnis dan dokumen-dokumen terkait proses bisnis, menjadi spesifikasi aturan kualitas data (data quality rule specification). Tahapan ini dilakukan untuk menerjemsahkan kebutuhan kualitas data yang telah diidentifikasi ke bagaimana kebutuhan kualitas data tersebut diimplementasikan dalam bentuk nyatanya. [18] menjelaskan salah satu cara bagaimana pernyataan bisnis diterjemahkan ke dalam spesifikasi aturan kualitas data. Contoh proses identifikasi aturan kualitas data ditunjukan dalam Tabel 4.

Tabel 4. Contoh proses identifikasi aturan kualitas data

\begin{tabular}{|c|c|c|}
\hline $\begin{array}{c}\text { Kode } \\
\text { Referensi }\end{array}$ & Datum Informasi Proses Bisnis & $\begin{array}{c}\text { Aturan Kualitas Data } \\
\text { Teridentifikasi }\end{array}$ \\
\hline W1-06 & $\begin{array}{l}\text { Kalau pendaftaran zaman sekarang yang } \\
\text { melalui SSCASN, data yang diisikan } \\
\text { banyak sekali sampai NIK orang tua, } \\
\text { pekerjaan ayah dan ibu, gaji ayah dan gaji } \\
\text { ibu, semua itu memang dibutuhkan dan } \\
\text { datanya memang dibutuhkan oleh PDDikti. } \\
\text { Jadi data mahasiswa yang seharusnya kita } \\
\text { miliki sekarang itu memang harus lengkap } \\
\text { banget. }\end{array}$ & $\begin{array}{l}\text { Atribut nilai untuk } \\
\text { "Mahasiswa" harus terisi } \\
\text { tidak boleh kosong: } \\
\text { NIK Ayah } \\
\text { NIK Ibu } \\
\text { Pekerjaan Ayah } \\
\text { Pekerjaan Ibu } \\
\text {... }\end{array}$ \\
\hline N-E1-12 & $\begin{array}{l}\text { Khusus mahasiswa Tingkat I, Indeks } \\
\text { Prestasi harus memenuhi semua kriteria } \\
\text { berikut: Mahasiswa memperoleh minimal } \\
\text { huruf mutu C untuk mata kuliah inti yang } \\
\text { telah ditentukan, IPS >=2,00 untuk } \\
\text { semester I dan II, Apabila syarat tersebut } \\
\text { tidak terpenuhi, maka mahasiswa tersebut } \\
\text { dinyatakan drop out (DO). }\end{array}$ & $\begin{array}{l}\text { Jika status mahasiswa tidak } \\
\text { drop out dan naik ke } \\
\text { tingkat II, maka }\left(\sum \text { nilai }\right. \\
\text { mata kuliah semester* SKS } \\
\text { mata kuliah semester }) /\left(\sum\right. \\
\text { SKS mata kuliah semester }) \\
\text { untuk tingkat I semester I } \\
\text { dan semester II minimal >= } \\
2,00\end{array}$ \\
\hline
\end{tabular}

Dalam penelitian ini, proses identifikasi aturan kualitas data dikelompokan menurut hasil identifikasi kebutuhan kualitas data yang telah didapatkan pada tahapan sebelumnya. Pernyataan bisnis yang dikonversi menjadi spesifikasi kebutuhan kualitas data bersumber dari keterangan aktor proses bisnis melalui wawancara, dokumen-dokumen yang dirujuk dari keterangan aktor proses bisnis, serta narasi proses bisnis dari tahapan penelitian sebelumnya. Hasil dari identifikasi kualitas data adalah daftar aturan kualitas data yang dikelompokan menurut kebutuhan kualitas data.

\section{Penyusunan Matriks Penilaian Kualitas Data}

Berdasarkan hasil tahapan penggalian informasi proses bisnis serta tahapan identifikasi kebutuhan kualitas data dan aturan bisnis kualitas data, disusun matriks penilaian kualitas data. Penyusunan matriks penilaian kualitas data dilakukan dengan memetakan tahapan hasil-hasil analisis sebelumnya yaitu entitas data yang teridentifikasi dan siapa yang bertanggung jawab, apa kriteria kebutuhan kualitas data yang akan diuji, dan apa saja aturan-aturan kualitas data yang harus divalidasi, ke dalam suatu dokumen yang dapat dijadikan penilaian kualitas data. Matriks penilaian kualitas data adalah hasil akhir dari penelitian ini yang diharapkan dapat digunakan untuk menjadi salah satu acuan untuk mengevaluasi kualitas data Politeknik Statistika STIS.

http://sistemasi.ftik.unisi.ac.id 


\section{Hasil dan Pembahasan}

\section{Proses Bisnis}

Identifikasi proses bisnis di Organisasi Politeknik Statistika STIS dilakukan dengan menganalisis 13 dokumen-dokumen yang mengandung informasi proses bisnis seperti data kualitatif dan pengamatan dari peneliti sebagai mahasiswa. Proses-proses bisnis yang dianalisis dalam penelitian ini terbatas cakupannya pada proses bisnis yang berhubungan langsung penyelenggaraan pendidikan akademik, penelitian, dan pengabdian masyarakat. Untuk memudahkan identifikasi proses bisnis, informasi yang tersebar dari berbagai dokumen dikumpulkan menjadi satu dokumen terpadu berjudul "Narasi Proses Bisnis Penyelenggaraan Pendidikan Akademik, Penelitian, Dan Pengabdian Masyarakat". Dokumen narasi proses bisnis ini merupakan rangkuman tentang informasi proses bisnis Politeknik Statistika STIS yang terkait tentang penyelenggaraan pendidikan akademik, penelitian, dan pengabdian masyarakat. Proses-proses bisnis dalam organisasi Politeknik Statistika STIS yang berhasil diidentifikasi dan berhubungan langsung dengan penyelenggaraan pendidikan akademik, penelitian, dan pengabdian masyarakat dapat dilihat pada Tabel 5.

Tabel 5. Kegiatan Proses Bisnis yang Teridentifikasi

\begin{tabular}{|l|l|}
\hline \multicolumn{1}{|c|}{ No. } & \multicolumn{1}{|c|}{ Kegiatan Proses Bisnis } \\
\hline 1 & Seleksi Mahasiswa Baru \\
\hline 2 & Pembentukan Rombongan Belajar \\
\hline 3 & Alokasi Jadwal Kuliah dan Pergantian Jadwal Kuliah \\
\hline 4 & Pelaksanaan Kegiatan Perkuliahan \\
\hline 5 & Tindak Lanjut Ketidakhadiran dan Dispensasi \\
\hline 6 & Pelaksanaan Kuliah Umum \\
\hline 7 & Pelaksanaan Praktek Kerja Lapangan \\
\hline 8 & Pelaksanaan Ujian Semester \\
\hline 9 & Pelaksanaan Ujian Akhir Program Studi \\
\hline 10 & Penilaian Kegiatan dan Kemajuan Belajar Mahasiswa \\
\hline 11 & Pelayanan Alumni \\
\hline 12 & Penyelenggaraan Pengabdian Kepada Masyarakat \\
\hline 13 & Penyelenggaraan Penelitian Dosen \\
\hline 14 & Penyelenggaraan Seminar Ilmiah \\
\hline 15 & Penerbitan Publikasi Ilmiah \\
\hline
\end{tabular}

Identifikasi aktor proses bisnis dilakukan dengan menganalisis 269 datum yang bersumber dari dokumen narasi proses bisnis. Dari analisis kodifikasi untuk identifikasi aktor bisnis yang dilakukan dua siklus, diperoleh 12 aktor teridentifikasi terkait proses bisnis organisasi Politeknik Statistika STIS. Hasil identifikasi aktor proses bisnis setelah tahapan kodifikasi narasi proses bisnis adalah seperti yang ditampilkan pada Tabel 6 .

Tabel 6. Hasil Identifikasi Aktor Proses Bisnis Setelah Tahapan Kodifikasi

\begin{tabular}{lll}
\hline Kode Aktor & \multicolumn{1}{c}{ Aktor } & \multicolumn{1}{c}{ Deskripsi } \\
\hline AK-01 & PROGRAM STUDI & $\begin{array}{l}\text { Program Studi merupakan unsur pelaksana akademik yang } \\
\text { mempunyai tugas melaksanakan pendidikan vokasi tertentu di } \\
\text { bidang statistika dan komputasi statistik. }\end{array}$ \\
\hline AK-02 & DOSEN & Dosen adalah tenaga pendidik profesional di Perguruan \\
\hline
\end{tabular}




\begin{tabular}{|c|c|c|}
\hline & & Tinggi sesuai dengan bidang keilmuannya. \\
\hline AK-03 & MAHASISWA & $\begin{array}{l}\text { Mahasiswa adalah seseorang yang sedang menjalani } \\
\text { pendidikan di dalam masa studinya di Politeknik Statistika } \\
\text { STIS. }\end{array}$ \\
\hline AK-04 & BAAK & $\begin{array}{l}\text { Bagian Administrasi Akademik, dan Kemahasiswaan } \\
\text { merupakan unsur pelaksanaan administrasi yang mempunyai } \\
\text { tugas untuk melaksanakan pengelolaan administrasi akademik } \\
\text { dan kemahasiswaan. }\end{array}$ \\
\hline AK-05 & BAGIAN UMUM & $\begin{array}{l}\text { Bagian Umum merupakan unsur pelaksana administrasi yang } \\
\text { mempunyai tugas untuk melaksanakan administrasi umum. }\end{array}$ \\
\hline AK-06 & PIMPINAN & $\begin{array}{l}\text { Pimpinan Politeknik Statistika STIS terdiri dari Direktur dan } \\
\text { Wakil Direktur Politeknik Statistika STIS. }\end{array}$ \\
\hline AK-07 & PPPM & $\begin{array}{l}\text { Pusat Penelitian dan Pengabdian Kepada Masyarakat } \\
\text { merupakan unsur pelaksana akademik di bidang penelitian } \\
\text { dan pengabdian kepada masyarakat. }\end{array}$ \\
\hline AK-08 & $\begin{array}{l}\text { PENYELENGGARA } \\
\text { UJIAN SEMESTER }\end{array}$ & $\begin{array}{l}\text { Penyelenggara Ujian Semester adalah tenaga yang dikerahkan } \\
\text { BAAK untuk melakukan pengawasan dan koordinasi dalam } \\
\text { UTS maupun UAS. }\end{array}$ \\
\hline AK-09 & $\begin{array}{l}\text { PANITIA SELEKSI } \\
\text { PMB }\end{array}$ & $\begin{array}{l}\text { Panitia Seleksi Penerimaan Mahasiswa Baru adalah tenaga } \\
\text { yang dikerahkan oleh Politeknik Statistika STIS dan BPS } \\
\text { untuk mengikuti kepanitiaan Seleksi Penerimaan Mahasiswa } \\
\text { Baru. }\end{array}$ \\
\hline AK-10 & ALUMNI & $\begin{array}{l}\text { Alumni adalah mahasiswa yang telah menyelesaikan masa } \\
\text { studinya di Politeknik Statistika STIS. }\end{array}$ \\
\hline AK-11 & $\begin{array}{l}\text { BIRO } \\
\text { KEPEGAWAIAN BPS }\end{array}$ & $\begin{array}{l}\text { Biro Kepegawaian BPS berperan dalam seleksi penerimaan } \\
\text { mahasiswa baru Politeknik Statistika STIS. }\end{array}$ \\
\hline AK-12 & $\begin{array}{l}\text { BADAN } \\
\text { KEPEGAWAIAN } \\
\text { NEGARA }\end{array}$ & $\begin{array}{l}\text { Badan Kepegawaian Negara berperan dalam seleksi } \\
\text { penerimaan mahasiswa baru Politeknik Statistika STIS. }\end{array}$ \\
\hline
\end{tabular}

\section{Entitas Data}

Identifikasi entitas data dilakukan dengan menganalisis 269 datum yang bersumber dari dokumen narasi proses bisnis. Dari analisis kodifikasi untuk identifikasi aktor bisnis yang dilakukan dua siklus, diperoleh 31 entitas data teridentifikasi terkait proses bisnis organisasi Politeknik Statistika STIS. Hasil identifikasi entitas data berdasarkan tahapan kodifikasi narasi proses bisnis beserta hasil identifikasi aktor yang terkait pada entitas data tersebut ditampilkan pada Tabel 7. Kode aktor yang digunakan adalah berdasarkan hasil identifikasi aktor proses bisnis sebelumnya pada Tabel 6 .

Tabel 7. Hasil Identifikasi Entitas Data Setelah Tahapan Kodifikasi

\begin{tabular}{lll}
\hline $\begin{array}{c}\text { Kode } \\
\text { Entitas } \\
\text { Data }\end{array}$ & \multicolumn{1}{c}{ Entitas Data } & \multicolumn{1}{c}{$\begin{array}{c}\text { Kode Aktor Entitas Data } \\
\text { Terkait }\end{array}$} \\
\hline ED-01 & MAHASISWA & AK-01, AK-09, AK-04, AK-03 \\
\hline ED-02 & DOSEN & AK-01, AK-04, AK-02 \\
\hline ED-03 & KULIAH & AK-04, AK-02, AK-03, AK-01 \\
\hline ED-04 & MATA KULIAH & AK-01, AK-04, AK-02, AK-03 \\
\hline ED-05 & JADWAL KULIAH & AK-01, AK-04, AK-02, AK-03 \\
\hline ED-06 & ABSENSI KULIAH & AK-04, AK-02, AK-03 \\
\hline ED-07 & ROMBONGAN BELAJAR & AK-09, AK-04, AK-02, AK-03 \\
\hline ED-08 & INVENTARIS PERKULIAHAN & AK-05 \\
\hline ED-09 & DISPENSASI & AK-04, AK-03, AK-06 \\
\hline ED-10 & KULIAH UMUM & AK-01, AK-05, AK-02, AK-03, \\
& & AK-04, AK-06 \\
\hline
\end{tabular}




\begin{tabular}{lll}
\hline ED-11 & UJIAN SEMESTER & $\begin{array}{l}\text { AK-01, AK-04, AK-05, AK-02, } \\
\text { AK-03, AK-06, AK-08 }\end{array}$ \\
\hline ED-12 & ABSENSI UJIAN SEMESTER & AK-03, AK-08 \\
\hline ED-13 & UJIAN SUSULAN SEMESTER & AK-01, AK-04, AK-02, AK-03 \\
\hline ED-14 & UJIAN KOMPREHENSIF & AK-01, AK-04, AK-03 \\
\hline ED-15 & NILAI AKADEMIK & AK-01, AK-04, AK-02, AK-03 \\
\hline ED-16 & NILAI NONAKADEMIK & AK-04, AK-02, AK-03 \\
\hline ED-17 & BIMBINGAN SKRIPSI/TUGAS AKHIR & AK-01, AK-02, AK-03, AK-04 \\
\hline ED-18 & SKRIPSI/TUGAS AKHIR & AK-01, AK-02, AK-03, AK-04 \\
\hline ED-19 & SEMINAR SKRIPSI/TUGAS AKHIR & AK-01, AK-02, AK-03, AK-04 \\
\hline ED-20 & SIDANG SKRIPSI/TUGAS AKHIR & AK-01, AK-02, AK-03, AK-04 \\
\hline ED-21 & TAHAPAN PMB & AK-09, AK-12, AK-05, AK-11 \\
\hline ED-22 & PESERTA PMB & AK-09, AK-12, AK-11 \\
\hline ED-23 & LEGALISIR IJAZAH DAN & AK-04, AK-10 \\
\hline ED-24 & TRANSKRIP NILAI & \\
\hline ED-25 & IJAZAH SMA & AK-04, AK-10 \\
\hline ED-26 & ABDIMAS & AK-04, AK-10 \\
\hline ED-27 & PENELITIAN DOSEN & AK-07, AK-02, AK-03, AK-06 \\
\hline ED-28 & SEMINAR ILMIAH & AK-05, AK-02, AK-03, AK-07 \\
\hline ED-29 & PUBLIKASI SEMINAR ILMIAH & AK-06, AK-07 \\
\hline ED-30 & PUBLIKASI ILMIAH & AK-07 \\
\hline ED-31 & PRAKTEK KERJA LAPANGAN & AK-06 AK-05, AK-02, AK-03, \\
\hline & & AK-02, AK-03, AK-04, AK-07 \\
\hline
\end{tabular}

\section{Kebutuhan Kualitas Data}

Identifikasi kebutuhan kualitas data dilakukan dengan menganalisis 119 datum yang bersumber dari wawancara dari perwakilan aktor Dosen, BAAK, Program Studi, dan PPPM. Aktoraktor ini dipilih karena memiliki peran besar dalam pelaksanaan proses bisnis Politeknik Statistika STIS. Penghitungan jumlah kodifikasi didasarkan dari jumlah kombinasi pasangan dimensi kualitas data dengan entitas data untuk setiap datumnya. Dari hasil kodifikasi kebutuhan kualitas data, diperoleh jumlah kodifikasi sebanyak 239. Berdasarkan dimensi kualitas data, kodifikasi kebutuhan kualitas data mayoritas terdiri dari kelengkapan (completeness) dan akurasi (accuracy). Dimensi kualitas lain yang teridentifikasi dalam analisis kebutuhan kualitas data ini adalah kebenaran (validity), konsistensi (konsistensi), ketepatan waktu (timeliness), kewajaran (reasonableness), keterkinian (currency), dan keterlacakan (lineage). Kelengkapan merupakan dimensi kualitas data yang banyak terkode karena aktor-aktor proses bisnis banyak memberikan pernyataan mengenai kebutuhan data yang perlu tersedia ketika menjalankan kegiatan maupun memberi keputusan pada proses bisnis tertentu. Akurasi juga merupakan dimensi kualitas data yang banyak terkode karena aktor-aktor proses bisnis juga banyak memberikan pernyataan tentang bagaimana seharusnya hubungan data terhadap aturan dan protokol dalam pelaksanaan nyata proses bisnisnya. Jumlah kodifikasi kebutuhan kualitas data menurut dimensinya dijelaskan dalam Tabel 8.

Berdasarkan pengelompokan hasil kodifikasi kebutuhan kualitas data berdasarkan dimensi kualitas data dan entitas data, ditemukan bahwa entitas data "MAHASISWA" (ED-01), "DOSEN"(ED-02), dan "NILAI AKADEMIK" (ED-17), memiliki jumlah kodifikasi kebutuhan kualitas data yang relatif tinggi dari kode entitas lainnya. Jumlah kodifikasi tidak menunjukan secara pasti mana saja entitas data yang memiliki kecenderungan lebih penting dari entitas data lainnya, namun menggambarkan apa saja ekspektasi aktor proses bisnis terhadap kebutuhan kualitas data menurut entitas data yang ingin dipenuhi. Jumlah kodifikasi kebutuhan kualitas data menurut dimensi dan entitas datanya dijelaskan dalam Tabel 9. Kode entitas data yang digunakan pada Tabel 9 tersebut merujuk pada kode entitas yang tertera pada Tabel 7. 
Tabel 8. Jumlah Kodifikasi Kebutuhan Kualitas Data Menurut Dimensi Kualitas Data

\begin{tabular}{lr}
\hline \multicolumn{1}{c}{ Dimensi Kualitas Data } & Jumlah \\
\hline Kelengkapan (Completeness) & 114 \\
\hline Kebenaran (Validity) & 13 \\
\hline Akurasi (Accuracy) & 68 \\
\hline Keterkinian (Currency) & 8 \\
\hline Kewajaran (Reasonableness) & 8 \\
\hline Konsistensi (Consistency) & 14 \\
\hline Keterlacakan (Lineage) & 4 \\
\hline Ketepatan Waktu (Timeliness) & 10 \\
\hline Jumlah & 239
\end{tabular}

Tabel 9. Jumlah Kodifikasi Kebutuhan Kualitas Data Menurut Dimensi Kualitas Data Dan Kode Entitas Data

\begin{tabular}{|c|c|c|c|c|c|c|c|c|c|}
\hline \multirow{2}{*}{$\begin{array}{c}\text { Kode } \\
\text { Entitas } \\
\text { Data }\end{array}$} & \multicolumn{9}{|c|}{ Dimensi Kualitas Data } \\
\hline & 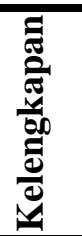 & 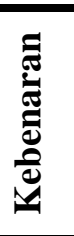 & 离 & 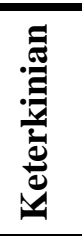 & 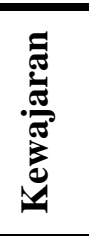 & 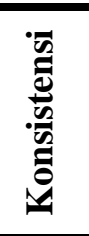 & 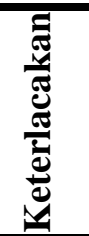 & 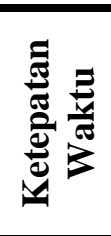 & 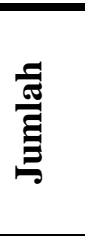 \\
\hline ED-01 & 14 & 0 & 12 & 2 & 1 & 7 & 0 & 0 & 36 \\
\hline ED-02 & 12 & 0 & 4 & 1 & 3 & 0 & 0 & 0 & 20 \\
\hline ED-03 & 5 & 0 & 2 & 0 & 0 & 0 & 0 & 0 & 7 \\
\hline ED-04 & 8 & 0 & 3 & 1 & 0 & 0 & 0 & 0 & 12 \\
\hline ED-05 & 1 & 1 & 3 & 0 & 2 & 0 & 0 & 1 & 8 \\
\hline ED-06 & 3 & 2 & 1 & 0 & 0 & 0 & 2 & 1 & 9 \\
\hline ED-07 & 2 & 0 & 2 & 1 & 1 & 0 & 0 & 0 & 6 \\
\hline ED-08 & 2 & 0 & 1 & 0 & 0 & 0 & 0 & 0 & 3 \\
\hline ED-09 & 0 & 0 & 0 & 0 & 0 & 0 & 0 & 0 & 0 \\
\hline ED-10 & 3 & 0 & 0 & 0 & 0 & 0 & 0 & 1 & 4 \\
\hline ED-11 & 6 & 0 & 2 & 0 & 0 & 0 & 0 & 3 & 11 \\
\hline ED-12 & 1 & 2 & 1 & 0 & 0 & 0 & 2 & 0 & 6 \\
\hline ED-13 & 1 & 0 & 3 & 0 & 0 & 0 & 0 & 0 & 4 \\
\hline ED-14 & 6 & 0 & 0 & 1 & 0 & 0 & 0 & 0 & 7 \\
\hline ED-15 & 6 & 5 & 8 & 0 & 0 & 0 & 0 & 1 & 20 \\
\hline ED-16 & 6 & 1 & 3 & 0 & 0 & 0 & 0 & 0 & 10 \\
\hline ED-17 & 4 & 0 & 0 & 0 & 0 & 0 & 0 & 0 & 4 \\
\hline ED-18 & 4 & 0 & 1 & 2 & 0 & 0 & 0 & 0 & 7 \\
\hline ED-19 & 3 & 0 & 1 & 0 & 1 & 0 & 0 & 0 & 5 \\
\hline ED-20 & 1 & 0 & 1 & 0 & 0 & 0 & 0 & 1 & 3 \\
\hline ED-21 & 0 & 0 & 0 & 0 & 0 & 0 & 0 & 0 & 0 \\
\hline ED-22 & 4 & 0 & 1 & 0 & 0 & 2 & 0 & 0 & 7 \\
\hline ED-23 & 1 & 0 & 1 & 0 & 0 & 0 & 0 & 0 & 2 \\
\hline ED-24 & 1 & 0 & 2 & 0 & 0 & 3 & 0 & 0 & 6 \\
\hline ED-25 & 2 & 0 & 4 & 0 & 0 & 2 & 0 & 0 & 8 \\
\hline ED-26 & 4 & 0 & 3 & 0 & 0 & 0 & 0 & 0 & 7 \\
\hline ED-27 & 4 & 0 & 5 & 0 & 0 & 0 & 0 & 0 & 9 \\
\hline
\end{tabular}




\begin{tabular}{lrrrrrrrrr}
\hline ED-28 & 3 & 0 & 1 & 0 & 0 & 0 & 0 & 1 & 5 \\
\hline ED-29 & 1 & 0 & 1 & 0 & 0 & 0 & 0 & 0 & 2 \\
\hline ED-30 & 0 & 2 & 1 & 0 & 0 & 0 & 0 & 1 & 4 \\
\hline ED-31 & 6 & 0 & 1 & 0 & 0 & 0 & 0 & 0 & 7 \\
\hline Jumlah & 114 & 13 & 68 & 8 & 8 & 14 & 4 & 10 & 239 \\
\hline
\end{tabular}

Entitas data "MAHASISWA" (ED-01) memiliki jumlah kodifikasi yang signifikan terhadap kelengkapan, akurasi, dan konsistensi. Hal ini selain bahwa entitas data mahasiswa merupakan entitas data yang kebutuhannya tinggi dalam kegiatan proses bisnis Politeknik Statistika STIS, juga dikarenakan berdasarkan keterangan aktor proses bisnis, entitas data tersebut memiliki isu-isu terutama mengenai kelengkapan, akurasi, dan konsistensi. Isu-isu yang disampaikan salah satunya adalah data mahasiswa yang tidak lengkap terutama untuk angkatan yang masuk sebelum tahun 2018. Ada ketidakkonsistenan dan ketidaktepatan antara nilai-nilai atribut data mahasiswa seperti nama, tempat, dan tanggal lahir antara dokumen dan sistem (contohnya ijazah SMA dan input saat PMB yang terekam sistem). Hingga ketika saat pencetakan ijazah dan transkrip nilai, ternyata ada kesalahan karena nama, tempat, atau tanggal lahir ada yang salah.

\section{Aturan Kualitas Data}

Identifikasi aturan kualitas data dilakukan dengan cara mengumpulkan datum-datum pernyataan aturan bisnis yang terdapat pada keterangan aktor proses bisnis dan dokumen terkait proses bisnis tersebut. Datum-datum tersebut lalu dikonversi ke dalam spesifikasi aturan kualitas data. Spesifikasi aturan kualitas data dibuat menurut entitas data dan kebutuhan kualitas data yang telah diidentifikasi sebelumnya. Berdasarkan tahapan identifikasi aturan kualitas data, peneliti berhasil mengidentifikasi 243 aturan kualitas data berdasarkan wawancara aktor proses bisnis dan narasi proses bisnis. Karena beberapa aturan kualitas data dapat terkait dengan lebih dari satu entitas data terkait, jika perhitungan jumlah aturan kualitas data memperhatikan banyaknya entitas data yang terkait, maka jumlah aturan kualitas datanya adalah 271. Mayoritas aturan kualitas data adalah terkait dengan dimensi kelengkapan. Jumlah dari aturan kualitas data yang teridentifikasi menurut dimensi kualitas datanya ditampilkan pada Tabel 10.

Tabel 10. Jumlah Aturan Kualitas Data Yang Teridentifikasi Menurut Dimensi Kualitas Data

\begin{tabular}{lrrr}
\hline $\begin{array}{c}\text { Dimensi Kualitas Data dalam Aturan } \\
\text { Kualitas Data }\end{array}$ & $\begin{array}{c}\text { Jumlah } \\
\text { Aturan }\end{array}$ & $\begin{array}{c}\text { Jumlah Aturan x Entitas } \\
\text { Data Terkait }\end{array}$ \\
\hline Kelengkapan (Completeness) & 180 & 180 \\
\hline Kebenaran (Validity) & 10 & 11 \\
\hline Akurasi (Accuracy) & 35 & 56 \\
\hline Kemutakhiran (Currency) & 6 & 6 \\
\hline Konsistensi (Consistency) & 2 & 3 \\
\hline Ketepatan Waktu (Timeliness) & 4 & 5 \\
\hline Keterlacakan (Lineage) & 6 & 10 \\
\hline Jumlah & 243 & 271 \\
\hline
\end{tabular}

\section{Matriks Penilaian Kualitas Data}

Berdasarkan hasil identifikasi entitas data dan aktor terkait, identifikasi kebutuhan kualitas data, dan identifikasi aturan kualitas data, dirancanglah matriks penilaian kualitas data untuk organisasi Politeknik Statistika STIS. Matriks penilaian kualitas data dikelompokan berdasarkan entitas data yang teridentifikasi sebelumnya. Elemen penilaian terdiri dari kelengkapan, akurasi, kebenaran, konsistensi, ketepatan waktu, kemutakhiran, dan keterlacakan. Peneliti tidak dapat mengidentifikasi aturan kualitas data kewajaran karena kebutuhan kualitas kewajaran yang diungkapkan aktor cenderung subjektif sehingga sulit diidentifikasi bagaimana cara mengukurnya. 
Elemen validasi terdiri dari aturan-aturan kualitas data yang teridentifikasi pada tahapan sebelumnya sesuai dengan elemen penilaian dan entitas datanya. Elemen aktor penanggung jawab entitas data adalah daftar aktor-aktor yang terkait dalam setiap entitas data kecuali aktor "MAHASISWA", "ALUMNI". Matriks penilaian kualitas data dapat digunakan menjadi perangkat untuk mengevaluasi kualitas data Politeknik Statistika STIS secara berkala agar sesuai dengan kebutuhan organisasi. Namun, pengujian matriks penilaian kualitas data tidak dilakukan pada penelitian ini. Peneliti menyarankan untuk dilakukan evaluasi terhadap matriks penilaian kualitas cara mengujinya langsung ke sistem database berjalan atau dokumen-dokumen yang disimpan serta diuji berdasarkan dengan pendapat ahli (expert judgement) di bidang manajemen kualitas data atau pendapat ahli pada proses bisnis Politeknik Statistika STIS terkait. Contoh matriks penilaian kualitas data ada pada

Tabel 11.

Tabel 11. Contoh Matriks Penilaian Kualitas Data

\begin{tabular}{llll}
\hline Nomor & $\mathbf{1 5}$ & & \\
\hline Entitas & Nilai Akademik & & \\
\hline $\begin{array}{l}\text { Penanggung } \\
\text { Jawab }\end{array}$ & BAAK, Program Studi, Dosen & Capaian \\
\hline Elemen Penilaian & Deskripsi & Validasi & \\
\hline Akurasi & $\begin{array}{l}\text { Mahasiswa yang naik } \\
\text { ke tingkat dua, IP untuk } \\
\text { Semester 1 dan } \\
\text { Semester 2 tingkat I } \\
\text { minimal 2,00. }\end{array}$ & $\begin{array}{l}\text { Jika status mahasiswa tidak drop } \\
\text { out dan naik ke tingkat II , maka }\left(\sum\right. \\
\text { nilai mata kuliah semester } * \text { SKS } \\
\text { mata kuliah semester) } /\left(\sum \text { SKS }\right. \\
\text { mata kuliah semester) untuk } \\
\text { tingkat I semester I dan semester II } \\
\text { minimal }>=2,00\end{array}$ \\
\hline
\end{tabular}

\section{$5 \quad$ Kesimpulan}

Berdasarkan hasil dan pembahasan yang telah disampaikan, dapat diambil beberapa kesimpulan. Tahapan identifikasi proses bisnis menghasilkan narasi proses bisnis yang merangkum 15 proses-proses bisnis teridentifikasi dalam organisasi Politeknik Statistika STIS yang berhubungan dengan penyelenggaraan pendidikan akademik, penelitian, dan pengabdian masyarakat. Tahapan pemodelan proses bisnis menghasilkan daftar aktor-aktor proses bisnis yang teridentifikasi sebanyak 12 aktor. Selain itu, dihasilkan pemodelan proses bisnis dalam diagram activity diagram. Tahapan identifikasi entitas data menghasilkan daftar entitas data proses bisnis yang teridentifikasi sebanyak 31 entitas data serta aktor-aktor proses bisnis yang terkait dengan entitas-entitas data tersebut.

Berdasarkan tahapan identifikasi kebutuhan kualitas data, dimensi-dimensi kualitas data yang teridentifikasi adalah kelengkapan, akurasi, kebenaran, konsistensi, ketepatan waktu, kewajaran, keterkinian, dan keterlacakan. Berdasarkan tahapan identifikasi aturan kualitas data, dihasilkan 243 aturan-aturan kualitas data yang terkait dengan dimensi kelengkapan, akurasi, kebenaran, konsistensi, ketepatan waktu, kemutakhiran, dan keterlacakan. Penelitian ini berhasil menyusun matriks penilaian kualitas sebagai salah satu acuan untuk mengevaluasi kualitas data organisasi Politeknik Statistika STIS.

Berdasarkan penelitian yang dilakukan, masukan untuk penelitian ini dan saran untuk penelitian selanjutnya antara lain Perlu dilakukan evaluasi tentang aturan kualitas data yang dihasilkan dari penelitian ini untuk menguji kelayakan hasil penelitian ini sebelum dijadikan referensi untuk kegiatan manajemen kualitas data di Politeknik Statistika STIS. Selain itu, penelitian dengan metode analisis kualitatif berupa metode kodifikasi seperti dalam penelitian ini sebaiknya dilakukan dalam tim. Hal ini bertujuan agar tingkat reliabilitas hasil analisis kodifikasi dapat diukur dengan baik. 1. Penelitian ini tidak memanfaatkan alat pendukung khusus seperti Computer-Assisted 
Qualitative Data Analysis Software (CAQDAS) untuk metode analisis data kualitatif, yang sebaiknya digunakan untuk meningkatkan kualitas hasil penelitian.

\section{Referensi}

[1] Badan Pusat Statistik, "Peraturan Kepala Badan Pusat Statistik nomor 87 tahun 2017 tentang organisasi dan tata kerja Politeknik Statistika STIS.” hal. 1-16, 2017.

[2] Republik Indonesia, Undang-Undang Tahun 2012 Tentang Pendidikan Tinggi. 2012.

[3] Menristekdikti, Peraturan Menteri Riset, Teknologi, dan Pendidikan Tinggi Nomor 61 Tahun 2016 Tentang Pangkalan Data Pendidikan Tinggi, Pangkalan Data Pendidikan Tinggi. 2016, hal. 61.

[4] W. Wijayanti, A. N. Hidayanto, N. Wilantika, I. R. Adawati, dan S. B. Yudhoatmojo, "Data quality assessment on higher education: A case study of institute of statistics," in 2018 International Seminar on Research of Information Technology and Intelligent Systems, ISRITI 2018, 2018, hal. 231-236.

[5] N. Wilantika dan W. C. Wibowo, "Data Quality Management in Educational Data," J. Sist. Inf., vol. 15, no. 2, hal. 52-67, 2019.

[6] M. Mosley, M. Brackett, S. Earley, dan D. Henderson, DAMA-DMBOK: Guide. 2009.

[7] D. Gagliardi, "Material data matter — Standard data format for engineering materials," Technol. Forecast. Soc. Change, vol. 101, hal. 357-365, 2015.

[8] L. Sebastian-Coleman, Measuring data quality for ongoing improvement: a data quality assessment framework. Newnes, 2012.

[9] P. H. S. Panahy, F. Sidi, L. S. Affendey, dan M. A. Jabar, "The Impact of Data Quality Dimensions on Business Process Improvement," in 2014 4th World Congress on Information and Communication Technologies, WICT 2014, 2014, hal. 70-73.

[10] D. Loshin, The Practitioner's Guide to Data Quality Improvement. Morgan Kaufmann, 2011.

[11] D. Plotkin, Data stewardship: An actionable guide to effective data management and data governance. Academic Press, 2020.

[12] C. Falge, B. Otto, dan H. Österle, "Data Quality Requirements of Collaborative Business Processes," in Proceedings of the Annual Hawaii International Conference on System Sciences, 2012.

[13] P. Mayring, "Qualitative content analysis," A companion to Qual. Res., vol. 1, no. 2, hal. 159$176,2004$.

[14] A. Dipalokareswara, H. Mubarok, dan A. K. Efendi, "Arsitektur Data dan Informasi untuk Mendukung Perancangan Data Warehouse Perumahan," J. Penelit. Sitrotika Univ. Siliwangi, 2014.

[15] D. Zaliluddin, "Enterprise Architecture Planning Sistem Informasi Perusahaan Manufaktur (Studi Kasus: CV . Harta Jaya Perusahaan)," Infotech J., 2012.

[16] C. J. Limanto, L. P. Dewi, dan A. Wibowo, "Pembuatan Arsitektur Data Di Perusahaan X," J. Infra, 2016.

[17] J. Saldaña, The Coding Manual for Qualitative Researchers (2nd Ed.). 2013.

[18] D. Plotkin, Data Stewardship. An Actionable Guide to Effective Data Management and Data Governance. Elsevier, 2014. 